\title{
Analisis Pengaruh Ukuran Perusahaan, Kualitas Auditor, Profitabilitas, dan Likuiditas terhadap Opini Going Concern pada Perusahaan Jasa
}

\author{
Jenifer Hutagaol', Erli Manurung ${ }^{2}$ \\ 1,2 Universitas Advent Indonesia \\ jeniferhutagaol@gmail.com ${ }^{1}$
}

\section{ARTICLE INFO}

Article History:

Received: June 30th 2021

Accepted: July $31^{\text {st }} 2021$

Published: August 9th 2021

Keywords:

Opinion Going Concern,

Company Size, Auditor's

Quality, Profitability,

Liquidity

\begin{abstract}
Tujuan dari penelitian ini adalah untuk menganalisis pengaruh ukuran perusahaan, kualitas auditor, profitabilitas dan likuiditas terhadap opini going concern pada perusahaan jasa yang terdaftar di Bursa Efek Indonesia periode 2016 sampai 2018. Penelitian ini merupakan penelitian kuantitatif dengan metode kausal komparatif dan menggunakan data sekunder. Populasi dalam penelitian ini meliputi seluruh sektor perusahaan jasa yang terdaftar di Bursa Efek Indonesia yang berjumlah 417 perusahaan. Sampel dalam penelitian ini berjumlah 33 (tiga puluh tiga) perusahaan, dengan teknik pengambilan sampel purposive sampling dan analisis data regresi logistik. Hasil penelitian ini menunjukkan bahwa kualitas dan likuiditas auditor berpengaruh negatif dan signifikan terhadap penerimaan opini going concern dengan tingkat signifikansi 0,014 dan 0,010 . Sedangkan ukuran perusahaan berpengaruh positif tetapi tidak signifikan dan profitabilitas berpengaruh negatif tetapi tidak signifikan terhadap penerimaan opini going concern dengan tingkat signifikansi 0,555 dan 0,431. Dan secara simultan variabel independen seperti ukuran perusahaan, kualitas auditor, profitabilitas, dan likuiditas semuanya berpengaruh signifikan terhadap variabel dependen yaitu opini going concern dengan tingkat signifikansi sebesar $88 \%$ dan sisanya sebesar $12 \%$ dipengaruhi oleh variabel lain selain penelitian.
\end{abstract}

\section{Pendahuluan}

Tujuan suatu perusahaan adalah memperoleh laba yang tinggi, akan tetapi laba yang tinggi tidak dapat menjamin keberlangsungan suatu perusahaan untuk jangka waktu yang lama. Ditambah persaingan dan perekonomian global yang mempengaruhi terhadap keuntungan yang diperoleh perusahaan. Melihat krisis ekonomi yang pernah terjadi pada tahun 1998 dan 2008 sangat jelas bahwa tidak hanya perusahan kecil yang berujung pada kebangkrutan, melainkan perusahaan besar pun mengalami collapse, sehingga dapat disimpulkan jika perusahaan skala besar dengan keuntungan besar pun tidak menjamin kepastian keberlangsungan usahanya. 
Tidak sedikit perusahan yang listing di Bursa Efek Indonesia harus dinyatakan delisting, yaitu penghapusan pencatatan saham di Bursa Efek Indonesia (BEI). Delisting sendiri bisa berupa sukarela atau paksa, dimana delisting paksa disebabkan karena keberlangsungan usaha perusahaan yang dipertanyakan dan tidak adanya penjelasan dari pihak manajemen perusahaan.

Akuntansi memiliki prinsip going concern, yaitu dimana sebuah bisnis atau usaha diharapkan dapat berjalan terus-menerus untuk jangka waktu yang lama. Ketika sebuah perusahaan mendapatkan opini mampu going concern, maka perusahaan tersebut akan mendapatkan trust dari investor ataupun kreditur karna dinilai dapat mempertahankan keberlangsungan usahanya dalam jangka waktu 12 bulan yang akan datang.

Banyak faktor yang perlu diperhatikan perusahaan dalam mempertahankan keberlangsungan usahanya, tidak hanya keuntungan saja yang menjadi fokus perusahaan, melainkan kemampuan pengelolaan aktiva serta kemampuan pemenuhan kewajibannya yang ditampilkan dalam laporan keuangan. Dalam pengelolaan aktiva, perusahaan harus dengan bijak mengalokasikan dana lancar atau penggunaan aktiva tetapnya, karena hal tersebut dapat membantu berjalannya suatu perusahaan baik dalam jangka pendek maupun jangka panjang.

Laporan keuangan berisikan informasi mengenai laporan posisi keuangan, laba rugi, perubahan ekuitas, arus kas dan catatan atas laporan keuangan. Laporan keuangan yang baik dapat memberikan informasi berkualitas mengenai kondisi perusahaan yang dimana informasi tersebut akan menjadi acuan bagi investor dalam keputusan untuk berinvestasi, sehingga auditor melakukan evaluasi melalui laporan keuangan perusahaan dan memberikan opini sesuai kondisi perusahaan yang sesungguhnya didalam laporan keuangan yang auditee.

Menurut Mutchler (1985) dalam penelitian Saifudin (2016) mengatakan bahwa auditor lebih sering mengeluarkan opini audit going concern pada perusahaan kecil karena auditor mempercayai bahwa perusahaan besar dapat menyelesaikan kesulitan-kesulitan keuangan yang dihadapinya daripada perusahaan kecil. Perusahaan besar dinilai memiliki akses yang lebih mudah dalam mendapatkan dana baik itu berupa pinjaman dari kreditur atau dana investasi dari investor.

Akan tetapi, pemberian opini going concern sendiri tetap berkaitan dengan reputasi auditor, karena adanya tuntutan dari masyarakat maupun pemerintah terhadap kredibilitas dan kualitas seorang akuntan publik menyebabkan reputasi akuntan publik dipertaruhkan. Dalam PSA No 30 SA 341 yang dikeluarkan oleh Ikatan Akuntan Indonesia (IAI), auditor bertanggung jawab untuk mengevaluasi apakah terdapat kesangsian besar terhadap kemampuan entitas dalam mempertahankan kelangsungan hidupnya dalam periode waktu pantas, tidak lebih dari satu tahun sejak tanggal laporan keuangan yang sedang diaudit.

Menurut DeAngelo (1981:184) dalam penelitian Barus (2016) menyatakan bahwa Kantor Akuntan Publik dengan ukuran lebih besar akan memiliki kualitas audit yang lebih tinggi. Semakin besar skala auditor maka akan semakin besar pula kemungkinan auditor untuk memberikan opini going concern (Aisiah, 2012). Oleh karena itu KAP dan auditornya memiliki peranan penting dan tanggung jawab yang besar dalam penyampaian opininya, auditor harus memiliki keberanian dalam menyampaikan kondisi perusahaan yang 
diauditnya, apakah dalam kondisi baik atau dalam kondisi tidak baik dan berdampak pada keberlangsungan hidup perusahaan klien.

Indikator going concern yang paling banyak digunakan auditor dalam memberikan keputusan audit adalah kegagalan dalam memenuhi hutangnya (PSA No.30), serta indikator-indikator lain seperti trend negatif, petunjuk lain tentang kemungkinan kesulitan keuangan, masalah intern, dan masalah yang telah terjadi. Jika dalam evaluasinya auditor berkesimpulan bahwa pengungkapan tidak memadai maka auditor akan memberikan pendapat wajar dengan pengecualian atau pendapat tidak wajar karena terdapat penyimpangan dari prinsip akuntansi yang berlaku umum di Indonesia.

Menurut Ginting dan Tarihoran (2017), investor cenderung akan lebih tertarik dalam berinvestasi pada perusahaan yang memperoleh pernyataan akan tetap going concern yang tidak diragukan dari auditor, hal tersebut disebabkan karena pernyataan going concern minimal memberikan kepercayaan kepada investor akan investasi yang akan dilakukan.

Penilaian dapat dilihat dari beberapa faktor, seperti pada faktor profitabilitas, yang merupakan pengukuran kemampuan perusahan dalam mencari keuntungan, juga mengukur tingkat efektivitas manajemen suatu perusahaan yang ditunjukkan dalam laba yang dihasilkan dari penjualan atau pendapatan investasi. Intinya adalah untuk menunjukkan efisiensi perusahaan (Kasmir, 2015:196).

Selain faktor profitabilitas ada juga faktor Likuiditas yang perlu dinilai. Likuiditas merupakan pengukuran kemampuan perusahaan dalam memenuhi kewajibannya yang sudah jatuh tempo, baik kewajiban kepada pihak luar perusahaan atau didalam perusahaan (Kasmir, 2015:129-130). Jika perusahaan mampu memenuhi kewajibannya, maka perusahaan tersebut dapat dikatakan dalam keadaan likuid, sedangkan sebaliknya jika perusahaan tidak mampu memenuhi kewajibannya maka perusahaan tersebut dikatakan dalam keadaan likuid.

\section{Kajian Teori dan Telaah Literatur}

\section{Pengertian Akuntansi}

Menurut Suyono Salamun (2012:2) Akuntansi dapat didefinisikan sebagai suatu system yang mengidentifikasi, mancatat, dan memproses informasi mengenai aktivitas bisnis suatu entitas menjadi laporan keuangan, dan mengkomunikasikan hasil usaha perusahaan kepada para pengambil keputusan.

\section{Laporan Keuangan}

Menurut Sofyan Syafri (2013:1) laporan keuangan adalah media informasi yang merangkum semua aktivitas perusahaan, informasi ini dapat digunakan untuk membantu pengambilan keputusan.

\section{Auditing}

Berdasarkan buku terjemahan yang ditulis oleh Alvin A. Arens, Randal J.elder, dan Mark S. Beasley (2017:4), Auditing adalah pengumpulan dan evaluasi bukti tentang informasi untuk menentukan dan melaporkan derajat kesesuaian antara informasi itu dan kriteria yang telah ditetapkan. 


\section{Opini Audit Going Concern}

Seperti yang sudah disebutkan dalam opini audit diatas, opini going concern merupakan informasi tambahan yang terdapat pada laporan audit Wajar Tanpa Pengecualian dengan paragraf penjelas. Dalam buku Arens (2017:66) menyatakan bahwa tujuan audit bukan untuk mengevaluasi kesehatan keuangan perusahaan, namun auditor memiliki tanggung jawab menurut SAS 59 (AU 341) untuk mengevaluasi apakah perusahaan mempunyai kemungkinan untuk tetap bertahan (going concern)

\section{Ukuran Perusahaan}

Menurut Riyanto (2010:22) ukuran perusahaan adalah besar kecilnya perusahaan dilihat dari besarnya nilai ekuitas, nilai penjualan atau nilai aktiva. Ukuran perusahaan adalah suatu ukuran, skala atau variabel yang menggambarkan besar-kecilnya perusahaan berdasarkan beberapa ketentuan, seperti total aktiva, log size, nilai pasar, saham, total penjualan, total pendapatan, total modal dan lain-lain.

\section{Kantor Akuntan Publik dan Kualitas Auditor}

Dalam buku Arens (2017:42) standard auditing merupakan pedoman umum untuk membantu auditor memenuhi tanggung jawab profesionalnya dalam audit atas laporan keuangan historis. Standar ini mencakup pertimbangan kualitas profesional seperti kompetensi dan independensi, persyaratan pelaporan, dan bukti.

\section{Analisis Rasio Keuangan}

Bagi pihak pemilik dan manajemen tujuan utama analisis laporan keuangan adalah agar dapat mengetahui posisi keuangan perusahaan saat ini, dengan mengetahui kondisi keuangan maka akan terlihat apakah perusahaan dapat mencapai target yang telah direncanakan sebelumnya atau tidak (Kasmir, 2015:66).

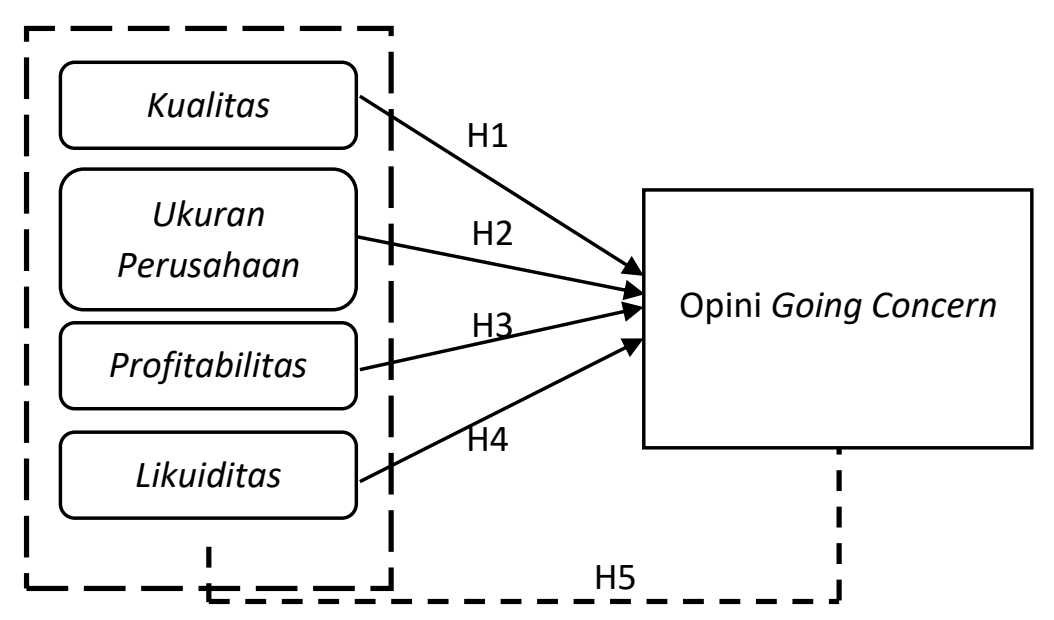

\section{Gambar 1. Model Penelitian}

$\mathrm{Ho}_{1}$ : Ukuran Perusahaan berpengaruh terhadap penerimaan opini going concern

$\mathrm{Ha}_{1}$ : Ukuran Perusahaan tidak berpengaruh terhadap penerimaan opini going concern

$\mathrm{Ho}_{2}$ : Kualitas Auditor berpengaruh terhadap penerimaan opini going concern

$\mathrm{Ha}_{2}$ : Kualitas Auditor tidak berpengaruh terhadap penerimaan opini going concern

$\mathrm{Ho}_{3}$ : Profitabilitas berpengaruh terhadap penerimaan opini going concern

$\mathrm{Ha}_{3}$ : Profitabilitas tidak berpengaruh terhadap penerimaan opini going concern

$\mathrm{Ho}_{4}$ : Likuiditas berpengaruh terhadap penerimaan opini going concern

$\mathrm{Ha}_{4}$ : Likuiditas tidak berpengaruh terhadap penerimaan opini going concern 
$\mathrm{Ho}_{5}$ : Ukuran Perusahaan, Kualitas Auditor, Profitabilitas, dan Likuiditas secara bersamasama berpengaruh terhadap penerimaan opini going concern

$H a_{1}$ : Ukuran Perusahaan, Kualitas Auditor, Profitabilitas, dan Likuiditas secara bersamasama tidak berpengaruh terhadap penerimaan opini going concern

\section{Metode Penelitian}

Penelitian ini merupakan penelitian kuantitatif dengan metode kausal komparatif. Menurut Indriantoro dan Supomo (2014:27) kausal komparatif merupakan penelitian dengan karakteristik masalah berupa hubungan sebab-akibat antara dua variabel atau lebih. Penelitian kuantitatif menurut Pandoyo dan Sofyan (2014:111) merupakan penelitian yang menekankan pada pengujian teori melalui pengukuran variabel penelitian dengan angka dan melakukan analisis data dengan prosedur statistik.

Populasi untuk penelitian ini yaitu perusahaan jasa yang tercatat di Bursa Efek Indonesia tahun 2016-2018 yaitu sebanyak 417 perusahaan. Sampel adalah salah satu bagian dari populasi yang menjadi perhatian (Suharyadi, 2016:6). Sehingga dalam penelitian ini sampel diambil menggunakan teknik purposive sampling dimana tahapan pengambilan sampel sebagai berikut:

Tabel 1. Kriteria Sampel

\begin{tabular}{lc}
\hline \multicolumn{1}{c}{ Kriteria } & Jumlah \\
\hline $\begin{array}{l}\text { Jumlah perusahaan sektor jasa yang listing di BEI tahun 2016-2018 } \\
\text { dan tidak mengalami delisting. }\end{array}$ & 417 \\
$\begin{array}{l}\text { Perusahaan sektor Infrastruktur, Utilitas, dan Transportasi } \\
\text { Perusahaan sektor Infrastruktur, Utilitas, dan Transportasi yang }\end{array}$ & 77 \\
$\begin{array}{l}\text { listing sebelum tanggal 1 Januari 2018 } \\
\text { Perusahaan yang mengeluarkan laporan keuangan periode 2016- }\end{array}$ & 37 \\
2018 dalam mata uang rupiah & 33 \\
\hline Jumlah perusahaan yang dijadikan sampel & 33 \\
\hline Periode penelitian (tahun) & $\mathbf{3}$ \\
\hline Jumlah sampel total selama periode penelitian & $\mathbf{9 9}$
\end{tabular}

\section{Variabel Dependen $(\mathrm{Y})$}

Variabel independen atau variabel bebas merupakan variabel yang mempengaruhi atau yang menjadi sebab perubahannya atau timbulnya variabel dependen (Sugiyono, 2014:39).

Variabel dependen pada penelitian ini bersifat dummy (dikotomi), yaitu menerima atau tidak menerima opini going concern. Dimana kode 0 untuk kategori "Tidak mendapat opini Going Concern" dan kode 1 untuk kategori "Mendapat opini Going Concern".

\section{Variabel Independen $(X)$}

\section{Ukuran Perusahaan}

Ukuran perusahaan dalam penelitian ini menggunakan perhitungan skala rasio dan diukur dengan menggunakan natural logarithm dari total aset oleh Yunita dan Rahayuningsih (2013 cit Makien).

$$
\operatorname{SIZE}\left(X_{1}\right)=\text { Ln }(\text { Total Aset })
$$




\section{Kualitas Auditor}

Variabel bebas yang kedua adalah kualitas auditor, menurut DeAngelo (1981:184) dalam penelitian Barus (2016) menyatakan bahwa Kantor Akuntan Publik dengan ukuran lebih besar akan memiliki kualitas audit yang lebih tinggi.

Dalam penelitian ini kualitas auditor diukur dengan menggunakan variabel dummy (dikotomi) dimana Kantor Akuntan Publik yang termasuk kategori Kantor Akuntan Publik berukuran besar atau big ten akan diberi kode 1, sedangkan Kantor Akuntan Publik yang tidak termasuk kedalam big 10 akan diberi kode 0 .

\section{Profitabilitas}

Profitabilitas merupakan kemampuan perusahaan dalam mendapatkan laba atau mencari keuntungan. Dalam penelitian ini untuk menghitung rasio profitabilitas peneliti menggunakan rasio keuangan return on assets (ROA), dengan rumus sebagai berikut:

$$
\text { Return On Asset }(\text { ROA })=\frac{\text { EAT }}{\text { Total Asset }}
$$

\section{Likuiditas}

Likuiditas merupakan kemampuan perusahaan dalam memenuhi kewajiban jangka pendeknya. Dalam penelitian ini untuk menghitung rasio profitabilitas peneliti menggunakan rasio keuangan Current Ratio (CR), dengan rumus sebagai berikut:

$$
\text { Current Ratio }(\text { CR })=\frac{\text { Current Assets }}{\text { Current Liabilities }}
$$

\section{Teknik Analisis Data}

Penelitian ini menggunakan analisis regresi logistik .berikut ini model regresi yang

\begin{tabular}{|c|c|}
\hline & $G C=\alpha+\beta_{1}\left(X_{1}\right)+\beta_{2}\left(X_{2}\right)+\beta_{3}\left(X_{3}\right)+\beta_{4}\left(X_{4}\right)+\in$ \\
\hline Y & : Opini Going Concern \\
\hline$\alpha$ & : Konstanta \\
\hline $\mathrm{X} 1$ & : Ukuran Perusahaan \\
\hline $\mathrm{X} 2$ & : Kualitas Auditor \\
\hline X3 & : Profitabilitas \\
\hline $\mathrm{X} 4$ & : Likuiditas \\
\hline$\beta_{1-4}$ & : Koefisien masing-masing variabel \\
\hline e & : error \\
\hline
\end{tabular}
digunakan: 


\section{Hasil dan Pembahasan}

Analisis Data

Hasil Uji Statistik Deskriptif

Tabel 2. Descriptive Statistics

\begin{tabular}{|c|c|c|c|c|c|}
\hline & $\mathbf{N}$ & Minimum & Maximum & Mean & Std. Deviation \\
\hline GC & 99 & 0 & 1 & ,16 & ,370 \\
\hline SIZE & 99 & 22,97 & 32,96 & 28,5937 & 2,07015 \\
\hline KA & 99 & 0 & 1 & ,65 & ,480 \\
\hline ROA & 99 & $-2,08$ & 2,19 &,- 0375 & 38386 \\
\hline CR & 99 & , 00 & 168,13 & 4,0912 & 19,65518 \\
\hline Valid N (listwise) & 99 & & & & \\
\hline
\end{tabular}

Sumber: Data diolah, 2020

\section{Hasil Uji Asumsi Klasik (Multikolinearitas)}

Untuk mendeteksi adanya multikolinear dalam model ialah dengan melihat nilai tolerance dan nilai Variance Inflation Factor (VIF) dimana nilai tolerance $>0,1$ dan nilai VIF $<10$ maka model dikatakan bebas multikolinieritas. Berdasarkan hasil penelitian dapat diketahui bahwa seluruh variabel bebasnya tidak terjadi multikolinearitas, hal tersebut dikarenakan nilai tolerance dari seluruh variabel tidak ada yang kurang dari 0,1 dan nilai VIF dari seluruh variabel pun tidak ada yang lebih dari 10.

\section{Hasil Uji Regresi Logistik}

\section{Hasil Uji Keseluruhan Model (Overall Model Fit)}

Dari hasil olah data dapat dilihat pada Block 0: Beginning Block nilai -2 Log Likelihood sebesar 87,583 dan pada Block 1: Method = Enter nilai -2 Log Likelihood sebesar 15,652. Terjadinya penurunan nilai -2 Log Likelihood ini mengartikan bahwa model telah fit dengan data dengan kata lain model regresi yang kedua atau pada Block 1: Method = Enter lebih baik.

\section{Hasil Uji Koefisien Determinasi (Nagelkerke R Square)}

Tabel 3. Model Summary

\begin{tabular}{cccc}
\hline Step & $\begin{array}{c}-2 \text { Log } \\
\text { likelihood }\end{array}$ & $\begin{array}{c}\text { Cox \& Snell R } \\
\text { Square }\end{array}$ & $\begin{array}{c}\text { Nagelkerke R } \\
\text { Square }\end{array}$ \\
\hline 1 & $15,652^{\mathrm{a}}$ &, 516 &, 880 \\
\hline \multicolumn{2}{c}{ Sumber: Data diolah, 2020} & &
\end{tabular}

Tabel diatas dapat menunjukkan tingkatan pengaruh atau kemampuan model dalam menerangkan pengaruh semua variabel independen secara bersamaan terhadap variabel dependennya. Dalam hasil uji diatas nilai Nagelkerke R Square sebesar 0,880 atau 88\% yang mengartikan bahwa sebesar $88 \%$ keempat variabel dalam model secara bersamaan mempengaruhi terhadap penerimaan opini going concern dan sebesar $12 \%$ yang didapat dari $100 \%-88 \%$, penerimaan opini going concern dipengaruhi oleh variabel lain diluar model.

\section{Hasil Uji Kelayakan Model Regresi (Goodness of Fit)}

Dari hasil olah data tabel Hosmer and Lemeshow's Test menunjukkan nilai Chi-square sebesar 1,758 dengan df 8 dan signifikansi 0,988 menunjukkan bahwa nilai signifikansi lebih dari 0,05 yang artinya tidak ada perbedaan antara klasifikasi yang diprediksi dengan klasifikasi yang 
diamati. Dengan kata lain model regresi logistik yang digunakan telah fit dengan data atau data layak untuk digunakan.

\section{Hasil Tabel Klasifikasi}

Tabel klasifikasi akan menunjukkan kekuatan prediksi dari model regresi dalam memprediksi kemungkinan penerimaan opini going concern pada perusahaan yang diteliti.

Tabel 3. Estimasi Parameter dan Interpretasinya

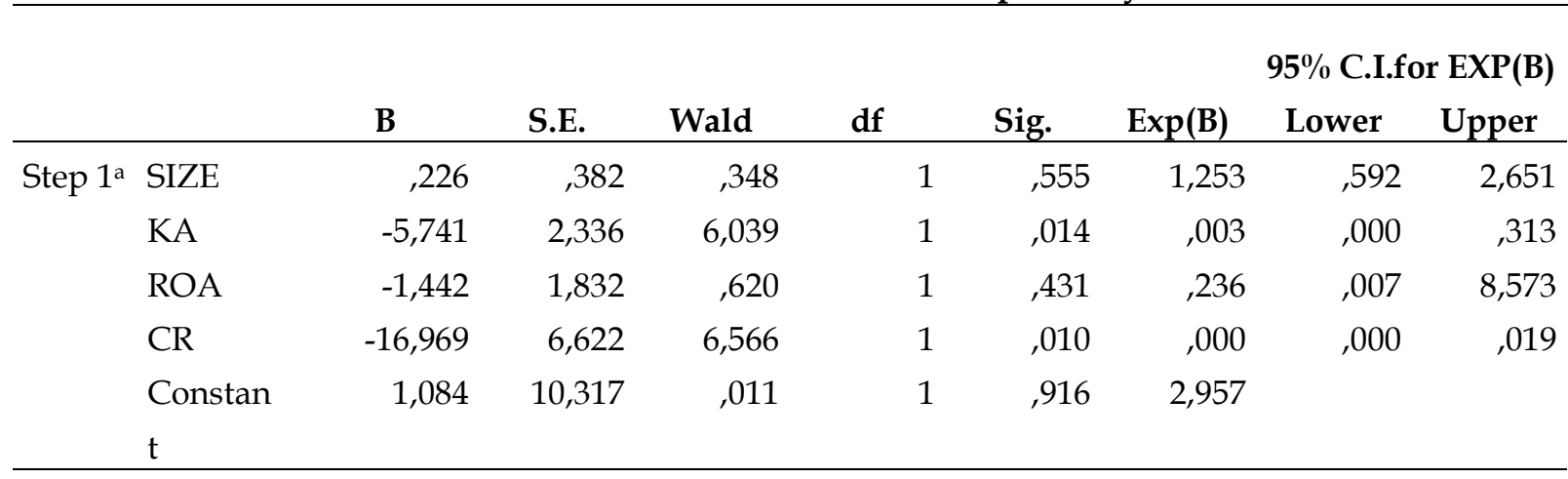

a. Variable(s) entered on step 1: SIZE, KA, ROA, CR.

Sumber: Data diolah, 2020

\section{Pengujian Hipotesis Penelitian}

\section{Uji Signifikansi Model Secara Parsial}

Dilihat dari tabel Variables in the Equation untuk variabel ukuran perusahaan memiliki nilai koefisien 0,226 dan nilai sig 0,555 lebih besar dari 0,05 yang artinya berpengaruh positif namun tidak signifikan.

Variabel kualitas auditor memiliki nilai koefisien $-5,741$ dan nilai sig 0,014 lebih kecil dari 0,05 yang artinya berpengaruh negatif dan signifikan.

Variabel profitabilitas memiliki nilai koefisien -1,442 dan nilai sig 0,431 lebih besar dari 0,05 yang artinya berpengaruh negatif namun tidak signifikan.

Variabel likuiditas memiliki nilai koefisien $-16,969$ dan nilai sig 0,010 lebih kecil dari 0,05 yang artinya berpengaruh negatif dan signifikan.

\section{Uji Signifikansi Model Secara Simultan}

Dapat dilihat dari tabel Model Summary pada nilai Nagelkerke R Square yaitu sebesar 0,880 yang artinya seluruh variabel independen secara bersama-sama mempengaruhi variabel dependennya sebesar $88 \%$.

\section{Penutup dan Saran}

\section{Simpulan}

Variabel kualitas auditor dan likuiditas berpengaruh negatif signifikan terhdap opini going concern, dan variabel ukuran perusahaan berpengaruh positif namun tidak signifikan, sedangkan variabel profitabilitas berpengaruh negatif namun tidak signifikan terhadap opini going concern. Secara simultan atau bersama-sama ukuran perusahaan, kualitas auditor, profitabilitas, dan likuiditas memiliki pengaruh sebesar $88 \%$ terhadap opini going concern. 


\section{Saran}

Berdasarkan kesimpulan yang didapatkan dari penelitian ini, maka saran yang dapat diberikan untuk penelitian selanjutnya adalah sebagai berikut:

1. Perusahaan

a. Perusahaan diharapkan mampu memperhatikan faktor-faktor yang mempengaruhi kelangsungan usaha.

b. Mengambil keputusan dengan bijak untuk masa yang akan datang.

2. Penetliti lain

a. Menggunakan alat ukur analisis rasio profitabilitas yang lain untuk variabel yang memiliki hasil tidak berpengaruh signifikan, contohnya mengubah penggunaan perhitungan return on assets menjadi return on equity atau yang lainnya.

b. Menambah variabel-variabel lain di luar penelitian ini yang memiliki potensi mempengaruhi penerimaan opini going concern pada perusahaan.

c. Memperluas sampel penelitian dan periode penelitian sehingga hasil yang diperoleh akan dapat lebih menggambarkan kondisi yang sesungguhnya.

3. Umum

Dapat menambah pengetahuan mengenai kelangsungan hidup usaha suatu entitas dan faktor-faktor yang mempengaruhinya.

\section{Referensi}

Adhityan, O., \& Taman, A. (2018). Pengaruh Ukuran Perusahaan, Likuiditas, Solvabilitas, Dan Profitabilitas Terhadap Opini Audit Going Concern. Jurnal Profita: Kajian Ilmu Akuntansi, 6(6).

Aiisiah, N. (2012). Pengaruh Kualitas Audit, Kondisi Keuangan Perusahaan, Opini Audit Tahun Sebelumnya, Pertumbuhan Perusahaan dan Ukuran Perusahaan Terhadap Kecenderungan Penerimaan Opini Audit Going Concern. Skripsi. Fakultas Ekonomi Universitas Diponegoro.

Arens, A. A., Elder, R. J., \& Beasley, M. S. (2017). Auditing dan Jasa Assurance Pendekatan Terintaergrasi. Jakarta: Penerbit Erlangga.

Badriyah, H. (2015). Praktis Menyusun Laporan Keuangan. Depok: Vicosta Publishing. Depok.

Barus, D. K. (2016). Pengaruh Kualitas Audit, Kondisi Keuangan Perusahaan, Opini Audit Tahun Sebelumnya dan Pertumbuhan Perusahaan Terhadap Opini Audit Going Concern pada Perusahaan Manufaktur yang Terdaftar di Bursa Efek Indonesia. Skripsi. Fakultas Ekonomi dan Bisnis Universitas Sumatra Utara.

Fahmi, I. (2017). Analisis Laporan Keuangan. Bandung: Penerbit Alfabeta.

Ghozali, I. (2018). Aplikasi Analisis Multivariate Dengan Program IBM SPSS 25. Semarang: Badan Penerbit Universitas Diponegoro.

Harahap, S. S. (2013). Analisis Kritis atas Laporan Keuangan. Jakarta: Penerbit Rajawali.

Hery. (2013). Akuntansi Perusahaan Jasa dan Dagang. Bandung: Penerbit Alfabeta.

Hery. (2016). Auditing dan Asurans: Pemeriksaan Akuntansi Berbasis Standar Audit Internasional. Jakarta: Penerbit PT Grasindo. 
Ikatan Akuntan Indonesia. (2001). Pernyataan Standar Auditing No 30 seksi 341. Jakarta.

Indriantoro, N., \& Supomo, B. (2014). Metodologi Penelitian Bisnis Untuk Akuntansi dan Manajemen. Yogyakarta: Penerbit BPFE-Yogyakarta.

Institut Akuntan Publik Indonesia. (2012). Standar Profesi Akuntan Publik SA 700 dan 705. Jakarta.

Kasmir. (2015). Analisis Laporan Keuangan. Jakarta: Penerbit Rajawali Pers.

Lie, C., Wardani, R. P., \& Pikir, T. W. (2016). Pengaruh likuiditas, solvabilitas, profitabilitas, dan rencana manajemen terhadap opini audit going concern (studi empiris perusahaan manufaktur di BEI). Berkala Akuntansi dan Keuangan Indonesia, 1(2).

Makien, A. (2016). Pengaruh Ukuran Perusahaan, Return on assets, Audit Tenure, Audit Lag, dan Proporsi Komisaris Independen Terhadap Opini Going Concern (Studi pada Perusahaan Sektor Jasa yang Terdaftar di BEI dan Menerima Opini Going Concern Periode 2010-2014). Skripsi. Fakultas Ekonomi dan Bisnis Universitas Islam Negeri Syarif Hidayatullah Jakarta.

Melania, S., Andini, R., \& Arifati, R. (2016). Analisis Pengaruh Kualitas Auditor, Likuiditas, Profitabilitas, Solvabilitas Dan Ukuran Perusahaan Terhadap Opini Audit Going Concern Pada Perusahan Manufaktur Yang Terdaftar Di Bursa Efek Indonesia. Journal Of Accounting, 2(2).

Pandoyo \& Sofyan. (2014). Metodologi Penelitian Keuangan dan Bisnis. Bogor: Penerbit IN MEDIA.

Prihadi, T. (2012). Memahami Laporan Keuangan Sesuai IFRS dan PSAK. Jakarta: Penerbit PPM.

Purwanto, S. (2016). Statistika Untuk Ekonomi dan Keuangan Modern. Jakarta: Penerbit Salemba Empat.

Riyanto, B. (2010). Dasar-dasar Pembelanjaan Perusahaan. Yogyakarta: BPFE.

Saifudin, A., \& Trisnawati, R. (2016). Pengaruh Ukuran Perusahaan, Profitabilitas, Likuiditas, Solvabilitas, Dan Pertumbuhan Perusahaan Terhadap Opini Audit Going Concern (Studi Empiris Pada Perusahaan Manufaktur Yang Terdaftar Di Bursa Efek Indonesia (Bei) Tahun 2011-2014). Skripsi. Universitas Muhammadiyah Surakarta

Salamun, S. (2012). Pengantar Akuntansi. Jakarta: Institute of Financial Market.

Salamun, S. (2014). Audit Keuangan. Jakarta Selatan: Penerbit IFM Publishing.

Sugiyono. (2014). Metode Penelitian Kuantitatif, Kualitatif, dan RED. Bandung: Penerbit Alfabeta.

Tarihoran, A. (2017). Faktor-faktor yang mempengaruhi pernyataan going concern. Jurnal Wira Ekonomi Mikroskil: Jwem, 7(1), 9-20.

Yusriwarti, Y., \& Mariyani, M. (2019). Pengaruh Kondisi Keuangan dan Kualitas Audit Terhadap Opini Audit Going Concern pada Perusahaan Manufaktur yang Terdaftar di Bursa Efek Indonesia. Jurnal Akuntansi dan Keuangan, 8(2), 51-60. 